\title{
Investigating the Effect of Masonry Infill Walls on the 2D RC Structural Systems with Asymmetry along the Elevation
}

\author{
İzzettin ALHALİL, M. Fethi GÜLLÜ* \\ Harran University, Faculty of Engineering, Civil Engineering Department, Şanluurfa, Turkey \\ (ORCID: 0000-0001-5409-1209) (ORCID: 0000-0002-6064-4719)
}

\begin{abstract}
Reinforced concrete (RC) frames with unreinforced masonry infill panels are common structural building systems all over the world. Although many analytical investigations and experimental observations emphasize the contribution of masonry infills to the overall stiffness and strength of the structures, their effects are not considered by the engineers in the design and the analysis calculations. Due to the variations in the actual behavior of the infill walls and using different parameters to define the infill walls in modeling and capacity calculations, they have unpredictable effects on the global response of the structural systems. The purpose of this study is the simulation of a collapse mechanism scenario that may be developed during the earthquake through applying incremental equivalent static load. Infill panels were represented using equivalent compression diagonal struts and their effects on the behavior of RC structural systems having asymmetrical placement of unreinforced masonry infill walls along the elevation has been scrutinized. The equivalent static load was applied to the structural system in $+/-X$ directions to focus on the effects of using only one diagonal strut. It has been observed that the influence of the infill panels on the structural system has beneficial effects in decreasing the story drift, which may be attributed to the contributory effect of the infill panels on the lateral stiffness of the structural system. Furthermore, the axial forces and bending moment diagrams have been plotted for each increment in the equivalent static load, which can give insight to understand the significance of masonry infill walls.
\end{abstract}

Keywords: Infill walls, seismic loading, equivalent diagonal strut.

\section{Yükseklik Boyunca Asimetrik 2B Betonarme Yapısal Sistemlerde Yığma Dolgu Duvarların Etkisinin İncelenmesi}

\begin{abstract}
$\ddot{O} z$
Güçlendirilmemiş yığma duvar dolgu panelleri kullanılarak oluşturulan betonarme çerçeveler, tüm dünyada yaygın olarak kullanılan yapısal sistemleridir. Birçok analitik araştırma ve deneysel gözlem, yığma dolgu duvarların yapıların genel rijitliğine ve dayanımına katkısını vurgulasa da, mühendisler tarafından tasarım ve analiz hesaplamalarında etkileri dikkate alınmamaktadır. Dolgu duvarların gerçek davranışlarında farklılıklar bulunması ve dolgu duvarları modelleme ve kapasite hesaplamalarında tanımlamak için kullanılan farklı parametreler nedeniyle, bu duvarlar yapısal sistemlerin genel tepkisi üzerinde öngörülemeyen etkilere sahiptirler. Bu çalışmanın amacı, deprem sırasında gerçekleşebilecek bir göçme mekanizması senaryosunun artımlı eşdeğer statik yük uygulanarak simülasyonudur. Dolgu duvarları eşdeğer diyagonal basınç elemanları kullanılarak temsil edilmiş ve yükseklik boyunca asimetrik olarak yerleştirilen güçlendirilmemiş yığma dolgu duvarların betonarme yapı sistem davranışı üzerindeki etkileri irdelenmiştir. Sadece bir çapraz destek kullanmanın etkilerine odaklanmak için yapısal sisteme eşdeğer statik yük +/- X yönlerinde uygulanmıştır. Dolgu duvarların yapısal sistemin kat yer değiştirmelerini azaltmada faydalı etkilere sahip olduğu gözlemlenmiştir. Bu durum dolgu duvarların yapısal sistem yanal rijitliği üzerinde katkı sağlayııı etkisine bağlanmaktadır. Ayrıca, eşdeğer statik yükteki her artış için eksenel kuvvetler ve eğilme momenti diyagramları çizilmiştir, bu da yığma dolgu duvarlarının önemini anlamak için fikir verebilir.
\end{abstract}

Anahtar Kelimeler: Dolgu duvarlar, sismik yükleme, eşdeğer diyagonal çubuk.

"Corresponding author: fethigullu@ harran.edu.tr

Received: 03.03.2021, Accepted: 16.05.2021 


\section{Introduction}

Masonry infill walls are a part of the traditional building systems used for separating the spaces in the architectural plans as well as providing acoustic and thermal insulation in the reinforced concrete (RC) structural systems. Since masonry infill walls are considered as non-structural members during the design process, most of the civil engineers do not consider the influence of them on the structural response. Recent earthquakes in the world showed that infill walls have generally beneficial effects on lateral load resisting of the structural systems, especially in high seismic regions [1-4]. The main problem in the masonry infills issue is the lack of a modeling approach that could reasonably simulate the actual behavior of the infilled frames. Infill panels are typically modeled using macro-modeling approach, which is preferred as a simple concept to predict the global behavior of the structural systems, or micro-modeling approach that may assist in predicting the local response and failure modes of the infilled frames. However, due to the requirements of supercomputers and long times for the analysis of structural systems, using micro-modeling approaches of masonry infill walls is not stated in design codes (e.g., FEMA-356, [5]).

The latest version of the Turkish Seismic Code [6] has some modifications and improvements compared to the previous version, in terms of natural vibration period [7] and soil classes [8]. These code provisions can be reliably used to evaluate the seismic performance of buildings (see also [9-11]). Masonry infill walls have been mentioned in some areas of the code, but require further updates in this regard.

Many researchers have been studied experimentally and numerically on masonry infilled steel and reinforced concrete (RC) frames to understand their mechanism through applying lateral load on the structural systems. It was first proposed to simulate the behavior of infill walls as diagonal struts in 1960s, and this approach was modified later to obtain more accurate models. It is well understood that during applying the lateral load on the structural system having infilled frames, the infill panel works in compression across two diagonal corner joints and the strut in the orthogonal direction to the first one was in tension resulting in gaps between the infill panels and the surrounding frames. According to this concept, the methodology of the diagonal compression strut was created. Also, as a prediction of the failure mechanisms, five types of failure modes (i.e., corner crushing, sliding shear, diagonal compression, diagonal cracking, and failure in frame) were presented in the literature during the assessment of the masonry infilled frames [12] which may be occurred at both infill panels and frames. Although it is commonly known that the presence of infill panels can increase the lateral stiffness of the structures, modeling of these non-structural elements is neglected in current design codes. Besides, undesirable results in seismic design (e.g., short column effects) were not considered due not to the modeling of masonry infill walls. Therefore, the contribution of infill panels should not be ignored in the design calculations. On the other hand, in performance-based design codes [5] and numerous analytical studies [13-16], using only one diagonal strut is proposed with a defined backbone curve. In seismic analysis due to the presence of an earthquake ground motion having reversed cycle loading hysteresis, these types of approaches cannot adequately predict the damage occur in the other direction [17].

Within the scope of this study, the failure mechanism that has been developed in each strut was investigated to show the gradual effect of the presence or absence of masonry infill walls during seismic loading. The effect of masonry infill walls on the global response has been represented via simplifying the envelope capacity of the single diagonal strut approach available in the literature. The earthquake scenario was defined by increasing the equivalent static load and eliminating the struts that reach the compression load capacity at each earthquake loading step. The reversed cyclic effect of the earthquake load has also been simulated by first imposing the earthquake load in one direction $(+X)$ only on the model that has one diagonal strut for each infill wall. Secondly, the earthquake load has been applied in the opposite direction (-X) with again defining only one diagonal strut. Hence, collapse mechanisms due to reaching axial load capacity in masonry infill walls and internal forces under the earthquake scenario were presented for $+X$ direction and $-X$ direction. The aim of defining two earthquake scenarios in opposite directions using only one strut for simulation of masonry infill walls is to investigate the results on a $2 \mathrm{D}$ frame system having asymmetry along the elevation under earthquake load. 


\section{Analytical Modeling}

\subsection{Description of the Structural System}

Five-bays eight-story frame was investigated in this study by using the computer software SAP2000 [18]. The 2D frame system is assumed to be in İstanbul city which has coordinates as $40.9816929^{\circ}$ for latitude and $28.63929^{\circ}$ for longitude. The foundation is modeled as fixed support, the soil class is ZC, and the ductility level is assumed to be high by considering $\mathrm{R}=8$. The frame members were considered to resist the lateral load sufficiently. All columns and beams have 80x80 and 80x30 cross-sectional dimensions, respectively, and story height was defined as $3.5 \mathrm{~m}$. The frame has asymmetrical bay lengths along the elevation (i.e., different span lengths were considered as shown in Figure 1) which are intentionally chosen to highlight the severe effects of infill panels on a non-symmetric structural system and to provide a widespread solution approach for such analyses. The dead load of the infill walls and the structural members with a live load has been considered as the vertical loads existing on the 2D frame system. The concrete compressive strength is defined as $25 \mathrm{MPa}$ and the modulus of elasticity of concrete is $30000 \mathrm{MPa}$. Weight per unit volume of concrete and brick is $2500 \mathrm{~kg} / \mathrm{m}^{3}$ and $1922 \mathrm{~kg} / \mathrm{m}^{3}$, respectively. The poisson ratios for concrete and brick are 0.2 and 0.15 , respectively. All infill panels were modeled as single diagonal struts oriented opposite to the loading direction, from top left to the bottom right for the earthquake load in the $+\mathrm{X}$ direction, and from bottom left to the top right for the earthquake load in the $-\mathrm{X}$ direction, as they are assumed to carry only the compressive load. The connection between the struts and the surrounding frame members was considered pin-connection at both ends of the struts since they are only capable of carrying the applied axial load.

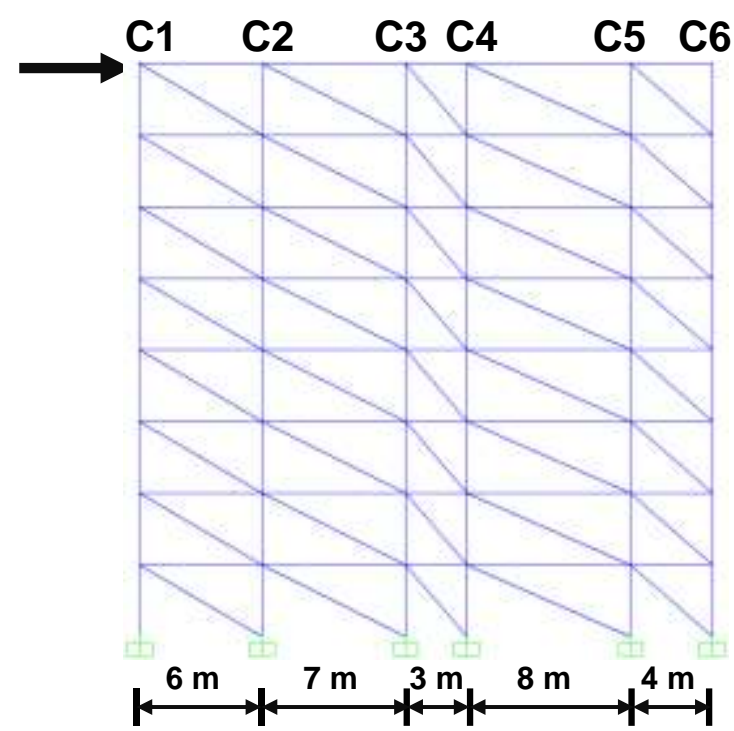

(a)

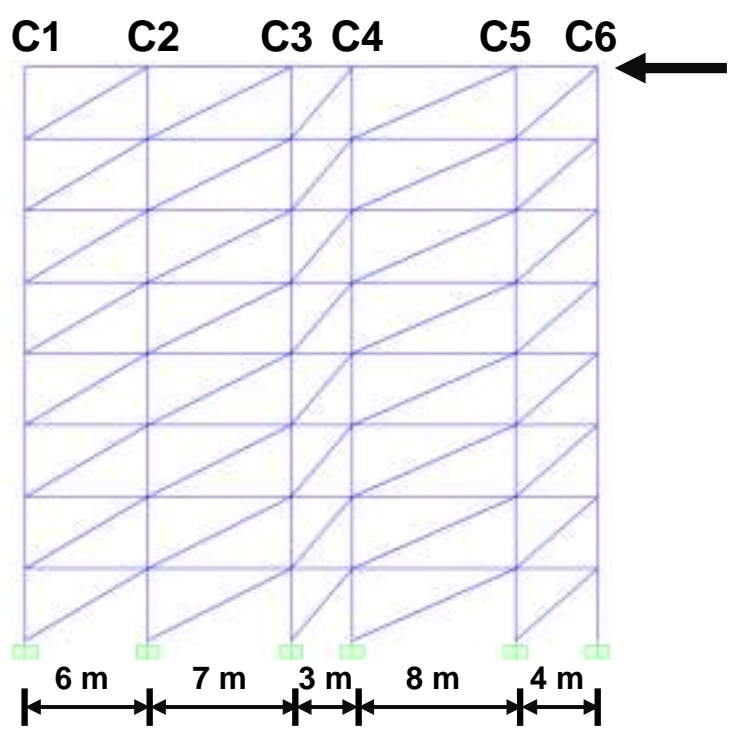

(b)

Figure 1. Model used in the analysis; (a) Earthquake load applied in $+\mathrm{X}$ direction, (b) Earthquake load applied in $-\mathrm{X}$ direction.

\subsection{Diagonal Strut Definition}

In literature, most researchers have been focused on the definition of the back-bone curve of the diagonal struts that have been used for simulation of masonry infill walls between frame members. Holmes [19] studied the stiffness and strength of infill panels with steel frames subjected to lateral shear force and carried out small-scale test specimens for comparison purposes. A simple procedure to determine the ultimate load and deflection in the frame was proposed. The diagonal strut width $\left(a_{i n f}\right)$ was assumed for the first time as;

$a_{\mathrm{inf}}=\frac{d_{\mathrm{inf}}}{3}$ 
where $d_{\text {inf }}$ is the diagonal length of infill walls. The ultimate load and deflection results obtained from the proposed equations were compared with the experimental small-scale test results and had a good agreement. However, these equations were valid only for infill panels having limited aspect ratios. In the study of "Stafford et. al. [20]", a design method based on an equivalent strut concept was developed to predict the lateral stiffness of the composite frames. The behavior of infilled frames under lateral load has been tested. The length of contact between the diagonal strut with the surrounding frame is one of the most important parameters used to determine the lateral stiffness and strength of the infill panel, which have been estimated by the following equation.

$a_{\mathrm{inf}}=0.58\left(\frac{1}{h_{\mathrm{inf}}}\right)^{-0.445}\left(\lambda_{h} H\right)^{0.335 d_{\mathrm{inf}}\left(\frac{1}{h_{\mathrm{inf}}}\right)^{0.064}}$

This equation was modified later by Mainstone and Weeks [21] as shown in the equation below;

$$
a_{i n f}=0.175 d_{i n f}\left(\lambda_{h} \mathrm{H}\right)^{-0.4}
$$

where $\lambda_{h}$ is the unitless parameter and can be calculated as:

$$
\lambda_{h}=\sqrt[4]{\frac{E_{\mathrm{inf}} \times t_{\mathrm{inf}} \times \sin (2 \theta)}{4 E_{c} \times I_{c} \times h_{\mathrm{inf}}}}
$$

In the above equations, $a_{\text {inf }}$ is the width of the diagonal strut, $I_{c o l}$ is the moment of inertia, $\mathrm{H}$ is the height of the column, $\theta$ is the angle between the infill length and diagonal length in radians, $E_{c}$ and $E_{i n f}$ are the expected elasticity modulus of the frame and infill panel, respectively, $h_{\text {inf }}$ is the height of the infill panel, $t_{\text {inf }}$ is the thickness of the infill panel and $d_{\text {inf }}$ is the diagonal length of the infill panel. To determine the width of the diagonal strut, FEMA-356 [5] use Equation 3 developed by Mainstone and Weeks [21]. Some of the other researchers [12], [22] proposed models based on single or multi-strut concepts trying to simulate the observed behavior of the diagonal strut.

In this study, the infill panels were modeled as single diagonal struts which only have axial compressive limits. The aim of using single strut only is to investigate the shortcomings of using one strut for simulation of infill walls and to show the behavioral response of the structural system which is expected to show discrepancy when the lateral load is applied in $+X$ and $-X$ directions. The width of the diagonal strut for each bay is presented numerically in Table 1 and plotted in Figure 2, where it was calculated according to FEMA-356 [5] equations. (as shown in Equation 3 and Equation 4). The values of the other parameters in Equations 3 and Equation 4 can be found in Table 2.

The material properties of the strut members were defined similarly to the brick masonry walls in literature, where the property of the infill wall materials and strut dimensions used in the analysis are assumed as follows. The modulus of elasticity of the masonry $\left(E_{i n f}\right)$ is 550 times the masonry prism strength $f_{m}^{\prime}$, where the mean value of $f_{m}^{\prime}$ is $4.1 \mathrm{MPa}, 6.6 \mathrm{MPa}$, and 7.5 $\mathrm{MPa}$ for prism constructed by weak, intermediate, and strong mortar, respectively [23]. In the current study the mortar was assumed to be intermediate $\left(f_{m}^{\prime}=6.6 \mathrm{MPa}\right)$ and the modulus of elasticity of masonry was calculated as $E_{\text {inf }}=$ $3630 \mathrm{MPa}$. Besides, the thickness of the diagonal strut is assumed to be $135 \mathrm{~mm}$ for all panels.

Table 1. The width of the diagonal strut for each infill panel

\begin{tabular}{ccccccc}
\hline Strut ID & $\begin{array}{c}\text { Bay length } \\
(\mathrm{m})\end{array}$ & $\begin{array}{c}r_{\text {inf }} \\
(\mathrm{mm})\end{array}$ & $\lambda$ & $\begin{array}{c}\theta \\
(\mathrm{rad})\end{array}$ & $\begin{array}{c}d_{\text {inf }} \\
(\mathrm{mm})\end{array}$ & $\begin{array}{c}a_{\text {inf }} \\
(\mathrm{mm})\end{array}$ \\
\hline 1 & 8 & 7689.6 & 1.446 & 0.359 & 7689.6 & 1161.1 \\
2 & 7 & 6762.4 & 1.485 & 0.411 & 6762.4 & 1010.2 \\
3 & 6 & 5859.2 & 1.527 & 0.479 & 5859.2 & 865.6 \\
4 & 4 & 4186.9 & 1.600 & 0.700 & 4186.9 & 607.1 \\
5 & 3 & 3482.9 & 1.597 & 0.877 & 3482.8 & 505.4 \\
\hline
\end{tabular}


Table 2. The parameters used to calculate the width of the diagonal strut

\begin{tabular}{cccccc}
\hline $\mathrm{H}(\mathrm{mm})$ & $t_{\text {inf }}(\mathrm{mm})$ & $I_{c}\left(\mathrm{~mm}^{4}\right)$ & $h_{\text {inf }}(\mathrm{mm})$ & $\begin{array}{c}E_{\mathrm{inf}} \\
(\mathrm{MPa})\end{array}$ & $\begin{array}{c}E_{c} \\
(\mathrm{MPa})\end{array}$ \\
\hline 3500 & 135 & $3.41 \mathrm{E}+10$ & 2700 & 3630 & 30000 \\
\hline
\end{tabular}

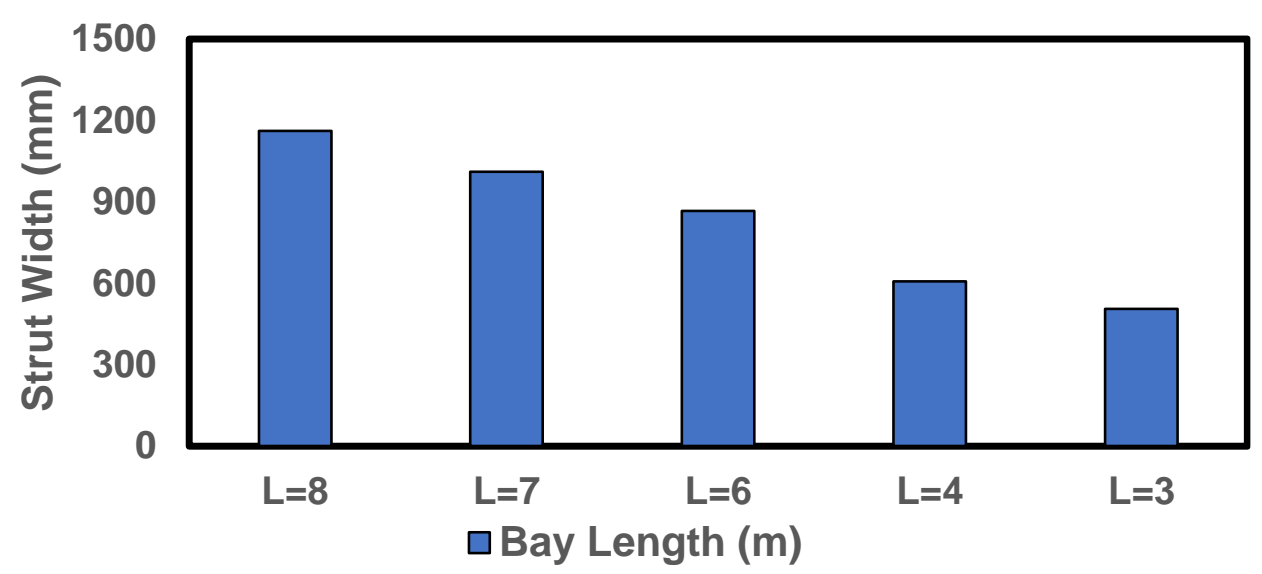

Figure 2. Diagonal strut width for each bay length

In addition to the definition of the cross-sectional dimensions of the diagonal struts, the axial load capacities of the diagonal struts have been calculated using one of the backbone curves mentioned in the literature and summarized herein. The seismic behavior of the infilled frames that had strong infill panels (i.e., infill panels constructed by strong mortar) was investigated by Panagiotakos and Fardis [24]. It was clearly shown that the strong infill wall that is generally considered as the non-structural element is effective for seismic resistance of RC frames. Panagiotakos and Fardis [25] conducted nonlinear seismic analyses, using the equivalent diagonal strut approach, which was quite simple due to being a macro modeling approach compared to the micro modeling approaches that need calculation effort and time. Tsai and Huang [26] investigated numerically the effects of masonry infill panels on the collapse mechanism of infilled RC frames with several positions of the infills in the plan and the elevation. According to their study, a new backbone curve was developed to determine the ultimate strength of the diagonal strut. Dolsek and Fajfar [27] similarly investigated a four-story RC building in case of the bare frame and infilled frame with and without openings. The infill panels were modeled using the diagonal compression strut approach for the sake of simplicity. They considered the expression proposed by Žarnić and Gostič [28] with a little simplification and suggested a new model as shown in Figure 3. The suggested model was capable of simulating the behavioral response of the experimentally observed results with good agreement. The model also provided results close to those calculated by Panagiotakos and Fardis [25]. Due to the reliability in predicting the experimental results, the backbone curve proposed by Dolsek and Fajfar [27] has already been chosen to obtain the capacity of the diagonal struts in the current study.

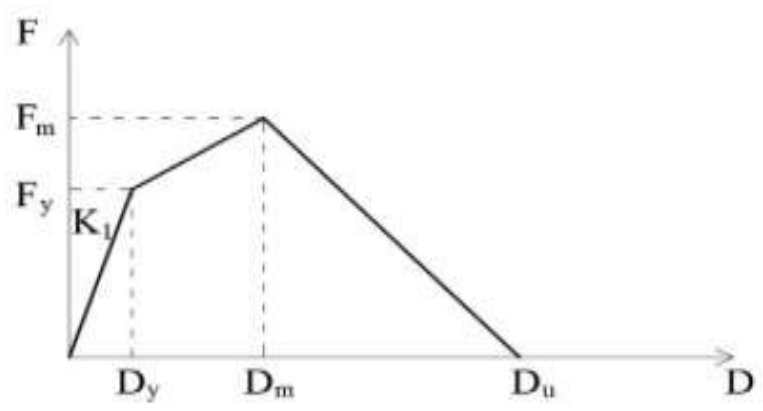

Figure 3. Force-displacement relationship for the diagonal strut [27]

In the backbone curve (Figure 3), initial stiffness was calculated as; 
$k_{1}=\frac{G_{w} \times t_{\text {inf }} \times L_{\text {inf }}}{h_{\text {inf }}}$

and the load capacity in the diagonal strut is defined as following;

$F_{m}=0.818\left(\frac{f_{t p} \times t_{\mathrm{inf}} \times L_{\mathrm{inf}}}{c_{1}}\right)\left(1+\sqrt{c_{1}^{2}+1}\right)$

where,

$c_{1}=1.925 \frac{L_{\text {inf }}}{h_{\text {inf }}}$

The cracking force $F_{y}$ was assumed as $60 \%$ of the maximum force $F_{m}$. The story drifts at maximum force $D_{m}$ is $0.2 \%$ for infill panel without opening. The ratio between the story drifts at zero load capacity $\left(D_{u}\right)$ and the maximum force $\left(D_{m}\right)$ was assumed to be 5 [27]. In the above equations, $t_{i n f}$ is the thickness of the infill panel, $L_{i n f}$, is the length of the infill panel and $h_{\text {inf }}$ is the height of the infill panel. $G_{w}$ is the shear modulus of the infill panel and $f_{t p}$ is the tensile strength of the infill panel obtained either from the diagonal tensile test or from the cyclic shear test of the masonry panel. The experimental results showed that $f_{t p}$ value varies tremendously depending on the mechanical characteristics of the masonry material itself [28]. The tensile strength and the shear modulus of the infill panel were assumed in the current research as $0.2 \mathrm{MPa}$ and $1452 \mathrm{MPa}$, respectively. Using the equation proposed by Dolsek and Fajfar [27] summarized above, the capacity of each strut was calculated and shown in Table 3.

Table 3. Capacity of the diagonal strut for each infill panel

\begin{tabular}{ccc}
\hline $\begin{array}{c}\text { Strut } \\
\text { ID }\end{array}$ & $\begin{array}{c}\text { Bay length } \\
(\mathrm{m})\end{array}$ & $\begin{array}{c}\text { Capacity } \\
(\mathrm{KN})\end{array}$ \\
\hline 1 & 8 & 192.99 \\
2 & 7 & 171.37 \\
3 & 6 & 149.93 \\
4 & 4 & 108.14 \\
5 & 3 & 82.68 \\
\hline
\end{tabular}

Some researchers studied on improving the seismic performance of infilled frame systems. Aksoylu and Kara [29-30] investigated RC frames strengthened by precast infill panels by conducting experimental tests on five (1:3 scaled) specimens under reversed-cyclic lateral loading and proposed a technique to improve the response of such infilled frame system. They concluded that this type of strengthening increases the stiffness, load carrying capacity, and energy dissipation capacity of the infilled frame as well as it can control the drift values within the limits.

\subsection{Analysis Procedure}

Analyses were conducted using the backbone curve capacity for the struts defined in the previous section with the applied equivalent static earthquake load on the frame system as per the Turkish Building Seismic Code (TBSC-2018) [6]. The analysis was divided into 10 steps in case of both $+X$ and $-X$ loading directions. The analysis procedure seems like a simulation of pushover analysis; however, it is a stepwise linear static analysis with scaled seismic loading for each step. The stepwise lateral loading was conducted to investigate the effect of the gradual failure of brick infill walls on the global response of the structural systems. This procedure was suggested for simulation of the infill panels even in humble linear-elastic analysis. In the first step, the frame was fully infilled, and after applying the lateral load, only one strut had reached capacity. In the second step, the strut that reached capacity in Step-1 was deleted from the model and the analysis proceeded for the remaining components. In this way, the other steps were conducted until most of the struts reached capacity. It is worth mentioning that if the applied 
earthquake load did not result in reaching the capacity of new struts in any one of the steps, the earthquake load was increased using a scale factor. It may seem awkward to scale earthquake load with an ad-hoc factor, however; the earthquake load was calculated using the design earthquake ground motion according to TBSC-2018 [6], and increasing it reasonable since it is well known that the actual ground motion may be bigger than the design earthquake. In each step, earthquake load was recalculated to consider the change in the mode shapes and periods due to the effect of extracting the struts that reached axial load capacity. The story masses were kept constant to focus on the effect of fails in infill panels on the lateral stiffness of the structural system. Also, it is aimed to see the effect of diagonal struts on the columns' internal forces, the lateral stiffness of the structural system, and the natural period of the 2D frame system under an arbitrary earthquake load. This method can show the global response of infilled frame by controlling the base shear levels to get new struts that reach the axial load capacity in each step.

\section{Discussion of Results}

Model descriptions with the analysis procedure are summarized in the previous section. In this section analysis results with the applied stepwise earthquake static load will be discussed. As it is explained, the struts that reach the lateral load capacity were assumed as failed and eliminated from the 2D frame model. The elimination of diagonal struts at each step is shown in Figure 4 for the applied earthquake static load in $+X$ and $-X$ directions. In the figure, the initials $S$ - means to the step. In common, using single strut is not capable of simulating the interaction between the infill and the surrounding frame, and the force distribution in frame elements accurately [31]. In this section, it is aimed to show the effect of using a single strut for modeling the infill walls in axial forces and bending moments of columns. The effects of deleting the struts to the natural period, drift ratios, story shear forces, and internal forces were separately discussed herein.

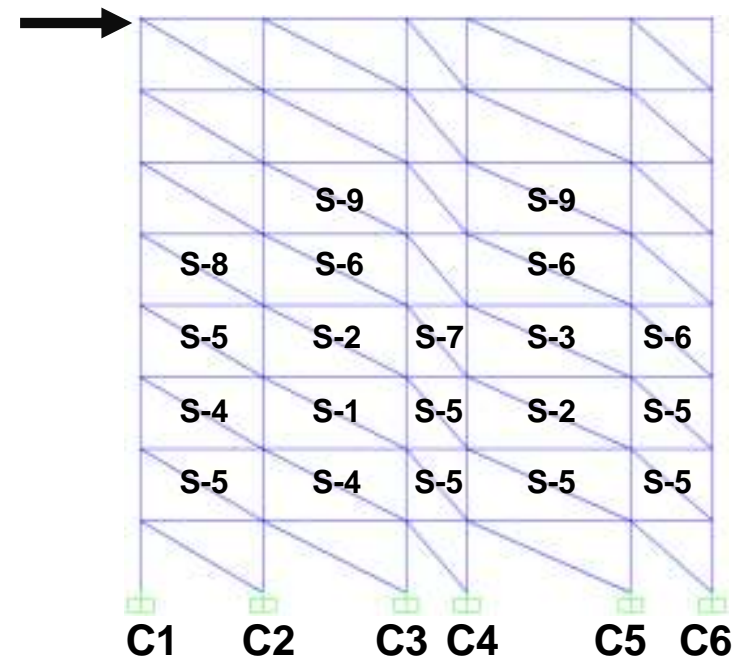

(a)

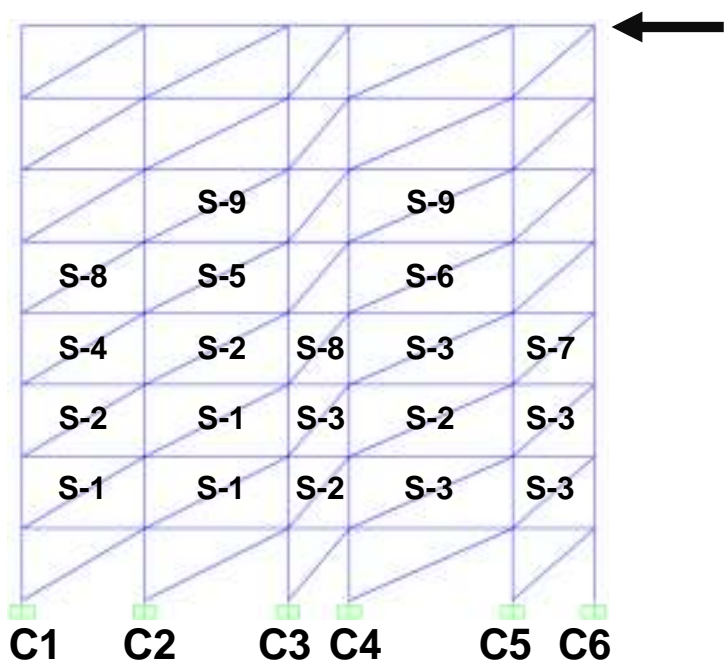

(b)

Figure 4. Step by step elimination of struts; (a) Earthquake load applied in $+X$ direction, (b) Earthquake load applied in -X direction.

\subsection{Effects of Natural Period of the 2D Frame System}

The natural periods of the 2D frame system for each step are shown in Table 4 with the corresponding base shear values, where the base shear values are the same for the $+X$ and $-X$ loading directions. Considerable differences in the natural periods can be recognized within the step numbers; S-2, S-3, S4 , and S-5. The reason for that may be attributed to the difference in the number of struts that were deleted due to reaching capacity. In the following steps with the increase in the earthquake load, natural periods are closer to each other, since the strut eliminations have become equal. Figure 5 shows the step number vs. natural periods for each step, which again manifests significant differences at the natural 
periods in the mid-steps. On the other hand, the bare frame has the greatest values of the natural period compared to the analysis for the infilled frame systems.

Table 4. Period and corresponding base shear for each step.

\begin{tabular}{cccc}
\hline Step number & $\begin{array}{c}\text { Base shear } \\
(\mathrm{kN})\end{array}$ & $\begin{array}{c}\text { Natural period } \\
(+\mathrm{X})\end{array}$ & $\begin{array}{c}\text { Natural period } \\
(-\mathrm{X})\end{array}$ \\
\hline S-1 & 1999.74 & 0.451 & 0.451 \\
S-2 & 1981.54 & 0.455 & 0.463 \\
S-3 & 1941.99 & 0.464 & 0.478 \\
S-4 & 1920.41 & 0.473 & 0.494 \\
S-5 & 2000.74 & 0.478 & 0.498 \\
S-6 & 1986.87 & 0.497 & 0.501 \\
S-7 & 2028.35 & 0.507 & 0.506 \\
S-8 & 2148.01 & 0.508 & 0.507 \\
S-9 & 2237.12 & 0.510 & 0.511 \\
S10 & 2387.78 & 0.517 & 0.517 \\
Bare frame & 1657.3 & 0.539 & 0.539 \\
\hline
\end{tabular}

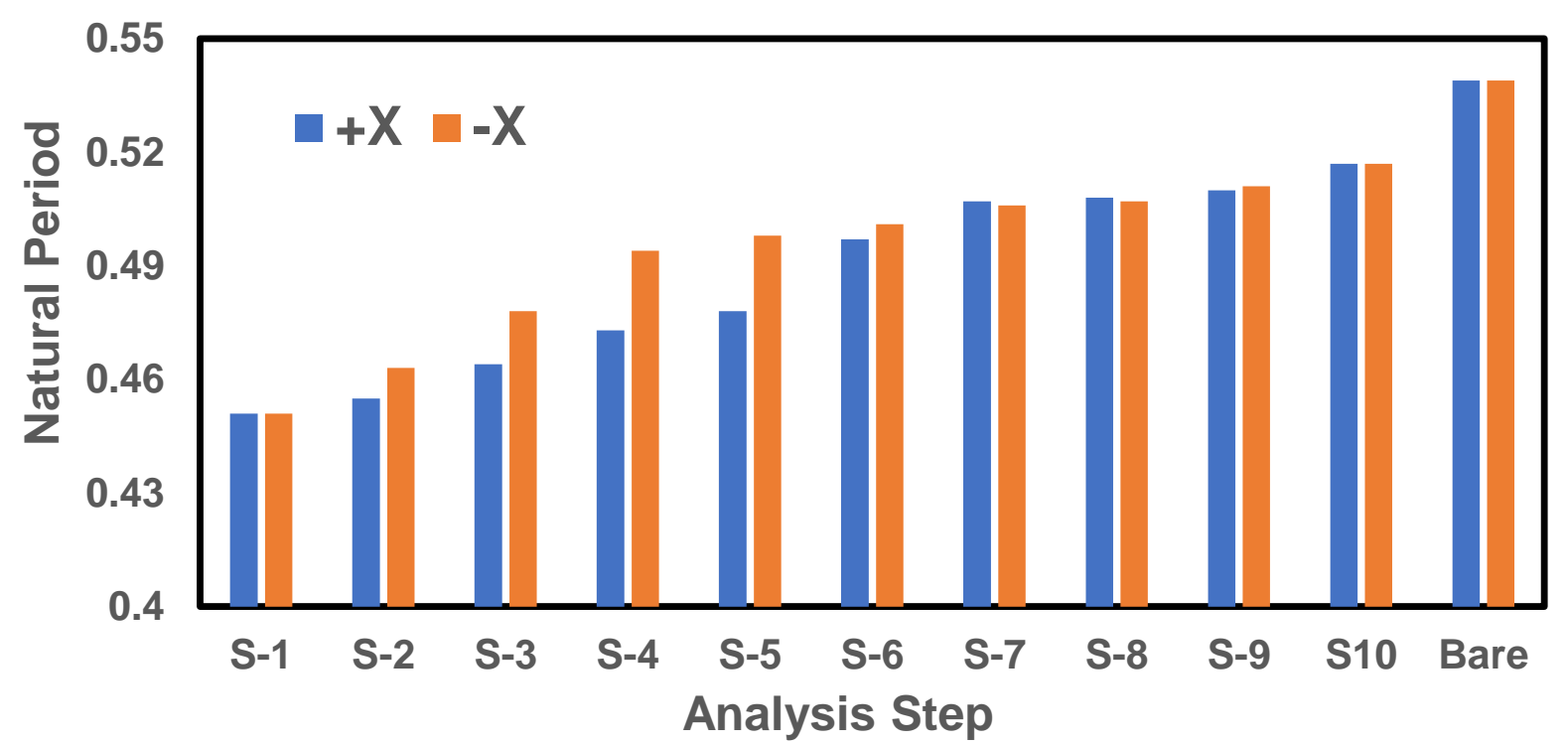

Figure 5. Natural periods for all steps in $+X$ and $-X$ loading directions.

\subsection{Effects on the Drift Ratio}

For comparison of the drift ratios for both $+\mathrm{X}$ and $-\mathrm{X}$ loading directions in the current study, the $2 \mathrm{D}$ frame system was also subjected to the earthquake ground motion levels that were calculated according to TBSC-2018 [6]. Four earthquake ground motion levels are defined in TBSC-2018 [6], which are DD1, DD2, DD3 and DD4. The design earthquake level of DD-2, which means to $10 \%$ probability of exceedance in 50 years (recurrence period 475 years) was first applied. In addition to the DD-2 level of the earthquake ground motion, DD-1 and DD-3 levels were also performed for 2D bare frames (B) and fully infilled frames (I). The earthquake ground motion levels were named as B-DD1, B-DD2 and BDD3 for bare 2D frames, and I-DD1 (+X), I-DD1 (-X), I-DD2, and I-DD3 for infilled 2D frames. Infilled 2D frame case means that the lateral load was applied on the fully infilled 2D frame, then the struts that reached axial load capacity have been deleted. After removing the struts that reached the axial load capacity, lateral load with the new natural period and mode shape has been applied again and the drifts have been recorded. It can be noted that in case of I-DD1, the drift ratios show differences in $+X$ and $\mathrm{X}$ cases. Hence, the I-DD1 load cases are shown separately in Figure 6 for $+\mathrm{X}$ and $-\mathrm{X}$ loading directions. Analyses results for 10 steps are completed and the result of drift ratios vs. building height are shown in Figure 6. Since the drift ratios indicate significant differences between $+X$ and $-X$ loading directions, their results are presented separately in the figures. Drift ratios can show a notable difference between drifts in $+\mathrm{X}$ with straight lines and in $-\mathrm{X}$ with dashed lines. This difference seems little in the first and 
the second steps; however, it has larger values in the later steps especially at the mid-height story levels where the simulated infill panels were failed due to reaching axial load capacity in the diagonal struts.

In TBSC-2018 [6], two equations (Equation 8 and Equation 9) have been defined to specify the limit of drift ratios depending on the connection details between the infill walls and the frame members. Equation 8 and Equation 9 are used to determine the drift limits for the infilled and bare frame, respectively.

$\lambda \frac{\delta_{i, \max }^{(X)}}{h_{i}} \leq 0.008 K$

$\lambda \frac{\delta_{i, \max }^{(X)}}{h_{i}} \leq 0.016 K$

In the equations above, $\lambda$ is the ratio of elastic design spectral acceleration of DD-3 to elastic design spectral acceleration of DD-2, $\mathrm{h}$ is the story height, $\delta_{\mathrm{i} \text {,max }}^{\mathrm{x}}$ is the maximum story drift of $\mathrm{i}^{\text {th }}$ story, and $\mathrm{K}$ is a coefficient taken as 1 for RC buildings. These two inter-story drift (ISDR) limits were calculated for the present case study and shown as vertical lines in Figure 6 . The drift ratio exceeds the limit of the infilled frame (considering the brick infill walls) in the last three steps of the analysis, while the drift ratios of the bare frame system (neglecting the brick infill walls) seem to be under the limits. The analysis results have shown that drift limits defined in TBSC-2018 [6] are sufficient for frame systems. Although the drift limits for the infilled frame system has been exceeded in the last three steps of the analysis, it is reasonable since most of the infilled walls has been reached their axial load capacity and deleted from the 2D frame system. 

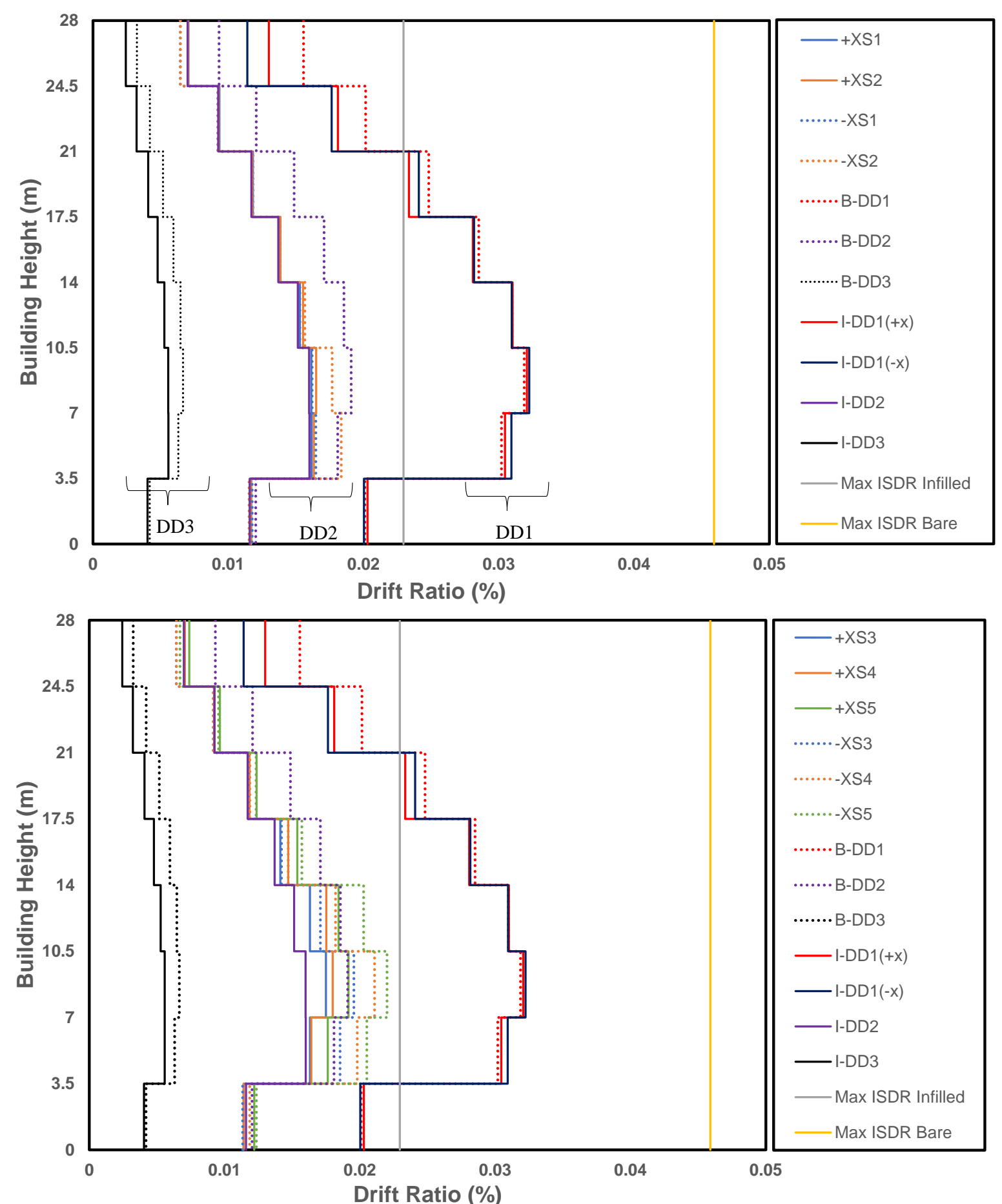

Figure 6. Drift ratios vs. Building height for all steps in $+X$ and $-X$ loading directions. 

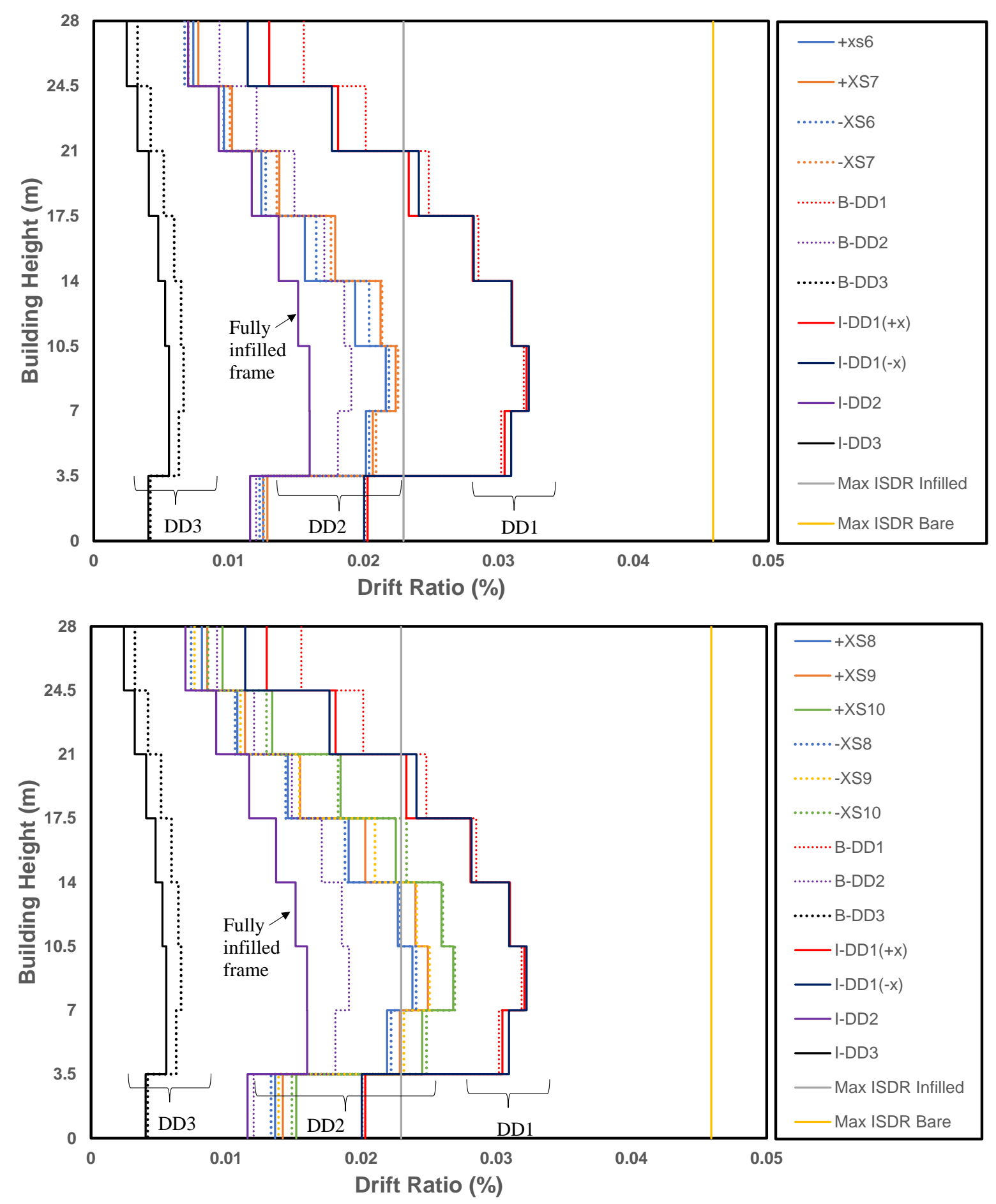

Figure 6. (Cont'd). Drift ratios vs. Building height for all steps in $+X$ and $-X$ loading directions.

\subsection{Effects on the Story Shear Forces}

Similar to the results presented for drift ratios, the story shear forces for $+X$ and $-X$ loading directions are presented in Figure 7. In the analysis process, although exclusion of diagonal struts due to reaching axial load capacity was different for $+X$ and $-X$ loading directions and natural periods was different especially in mid-steps, total base shear was enforced to be equal for both loading directions. Hence, as it is shown in Figure 7, the story shear forces for both loading directions are almost equal. However, it is worth mentioning that even for the linear analysis with the simplified approach used in this study, bare frame and infilled frame systems have considerable variations in the story shear forces and total base shear forces under the design earthquake ground motion (DD-2) and frequently observed 
earthquake ground motion (DD-3). For the DD1 earthquake ground motion level, the bare and infilled frame systems have nearly equal story shear forces and total base shear forces, which may be attributed to identical behavioral responses of both frame systems under this earthquake level.
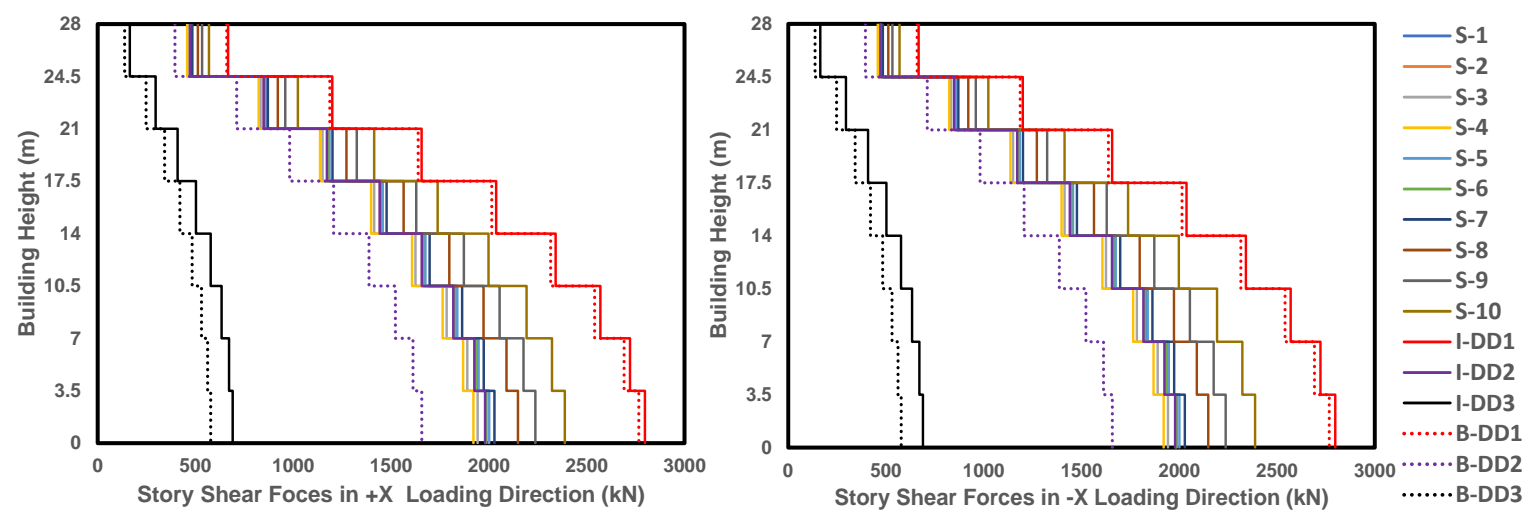

Figure 7. Story shear forces vs. Building height for all steps in $+\mathrm{X}$ and $-\mathrm{X}$ loading directions.

\subsection{Effects on the Axial Forces and Bending Moment of the Columns}

It is widely known that the presence or absence of infill panels can alter the axial force and bending moment distribution in the columns. The presence of the infill walls leads to a considerable effect on the axial force and bending moment interaction of the columns [32]. In the present study, the axial forces in columns have been normalized with base shear values for each step and plotted for both $+X$ and $-X$ loading directions in Figure 8, starting from Step-1 where just one strut at the third story has reached the axial load capacity until Step-10 where most of the struts reached the axial load capacity. Since the axial force distribution of the columns changed due to the exclusion of the struts that reached capacity, the axial compressive load in the first column increased with the higher step numbers. The column $\mathrm{C} 2$ is in tension in Step-1, however then, it tends to be in the compression field with the increasing step number under earthquake load in $+\mathrm{X}$ direction. For the earthquake load in $-\mathrm{X}$ direction, the axial force moved from compression to tension in column $\mathrm{C} 2$. There are similar trends in the normalized axial force values in the remaining columns. It is also worth mentioning that the absolute values of the axial forces on the columns differ from each other since the structural system is intentionally chosen not to be symmetrical along the elevation. Figures 9 and 10 show the normalized bending moment values at the top and bottom of the columns with the increasing step numbers along with the height of the $2 \mathrm{D}$ frame system. The normalized bending moment was calculated by dividing the bending moments with the total base shear and the height of the 2D frame system, which is significant to compare the results in the bending moments with neglecting the effect of the diversity in the earthquake load. With the increasing earthquake load, bending moment values also increase at the top and bottom of the columns. Comparing the bending moment plots for $+\mathrm{X}$ and $-\mathrm{X}$ loading directions at the top of the columns show similar trends at the initial and final steps; however, in the mid-steps model, results present slight diversity at the mid-stories due to extraction of diagonal struts that reached the axial load capacity. Again, similar results were obtained for the normalized bending moment values at the top of the columns (Figure 10). Due to deleting the struts, the bending moment values diverse in the mid-height of the 2D frame system between $+X$ and $-X$ loading directions, revealing that considering the effect of the infill walls is inevitable since they may provide either advantageous or disadvantageous effects on the structural systems under lateral loading. 

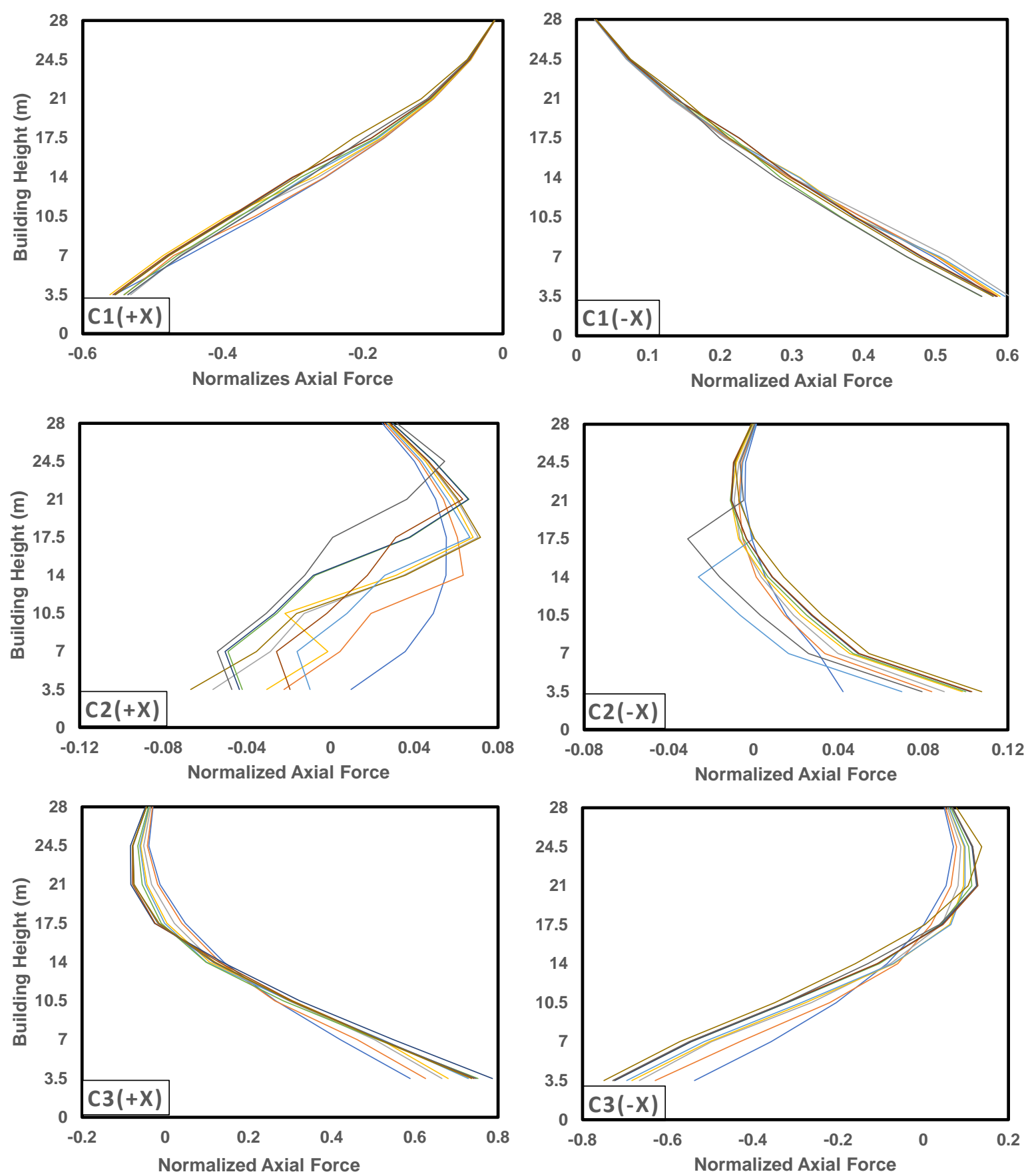

\begin{tabular}{|rrrrr|}
\hline S-1 & $-\mathrm{S}-2$ & $\mathrm{~S}-3$ & $\mathrm{~S}-4$ & S-5 \\
S-6 & $-\mathrm{S}-7$ & $\mathrm{~S}-8$ & $\mathrm{~S}-9$ & $-\mathrm{S}-10$ \\
\hline
\end{tabular}

Figure 8. Normalized axial forces vs. Building height in columns for all steps in $+/-X$ loading directions. 

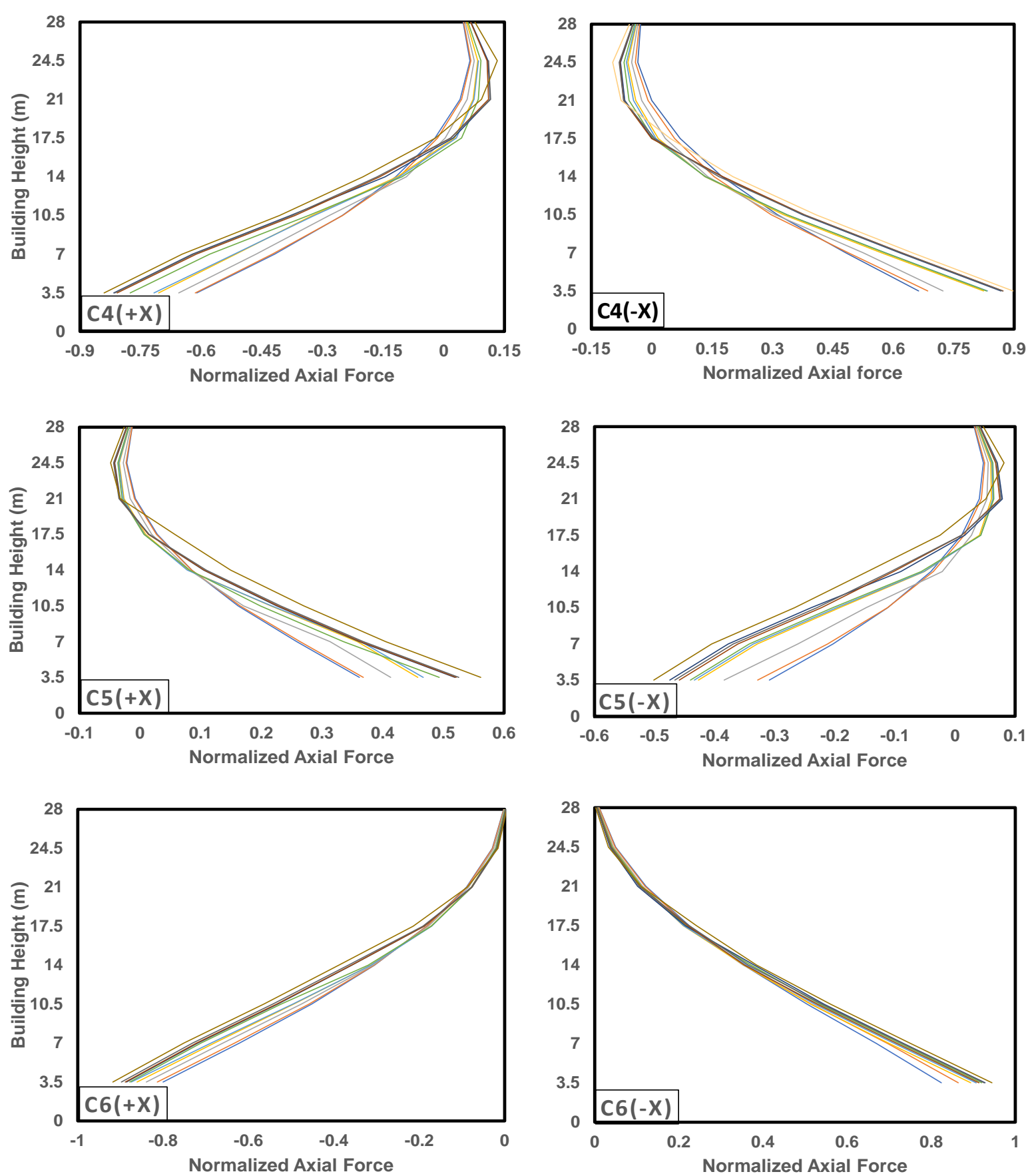

\begin{tabular}{|rrrrr|}
\hline S-1 & S-2 & S-3 & S-4 & S-5 \\
S-6 & $-S-7$ & S-8 & S-9 & S-10
\end{tabular}

Figure 8. (cont'd). Normalized axial forces vs. Building height in columns for all steps in $+/-X$ loading directions. 

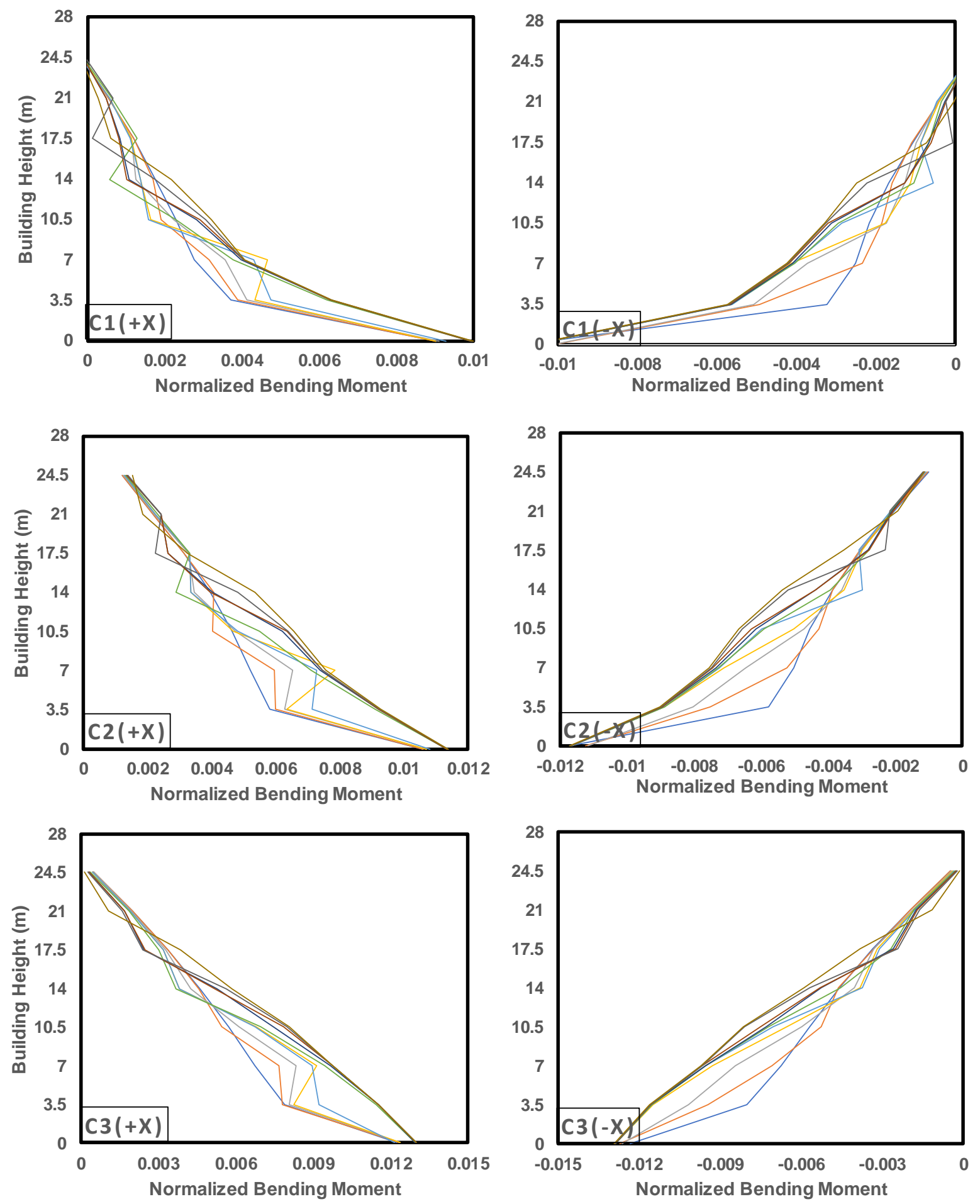

$$
\begin{array}{|rrrrr|}
\hline \text { S-1 } & \text { S-2 } & \text { S-3 } & \text { S-4 } & \text { S-5 } \\
\text { S-6 } & \text { S-7 } & \text { S-8 } & \text { S-9 } & \text { S-10 } \\
\hline
\end{array}
$$

Figure 9. Normalized bending moments vs. Building height at the bottom of the columns for all steps in $+/-X$ loading directions. 

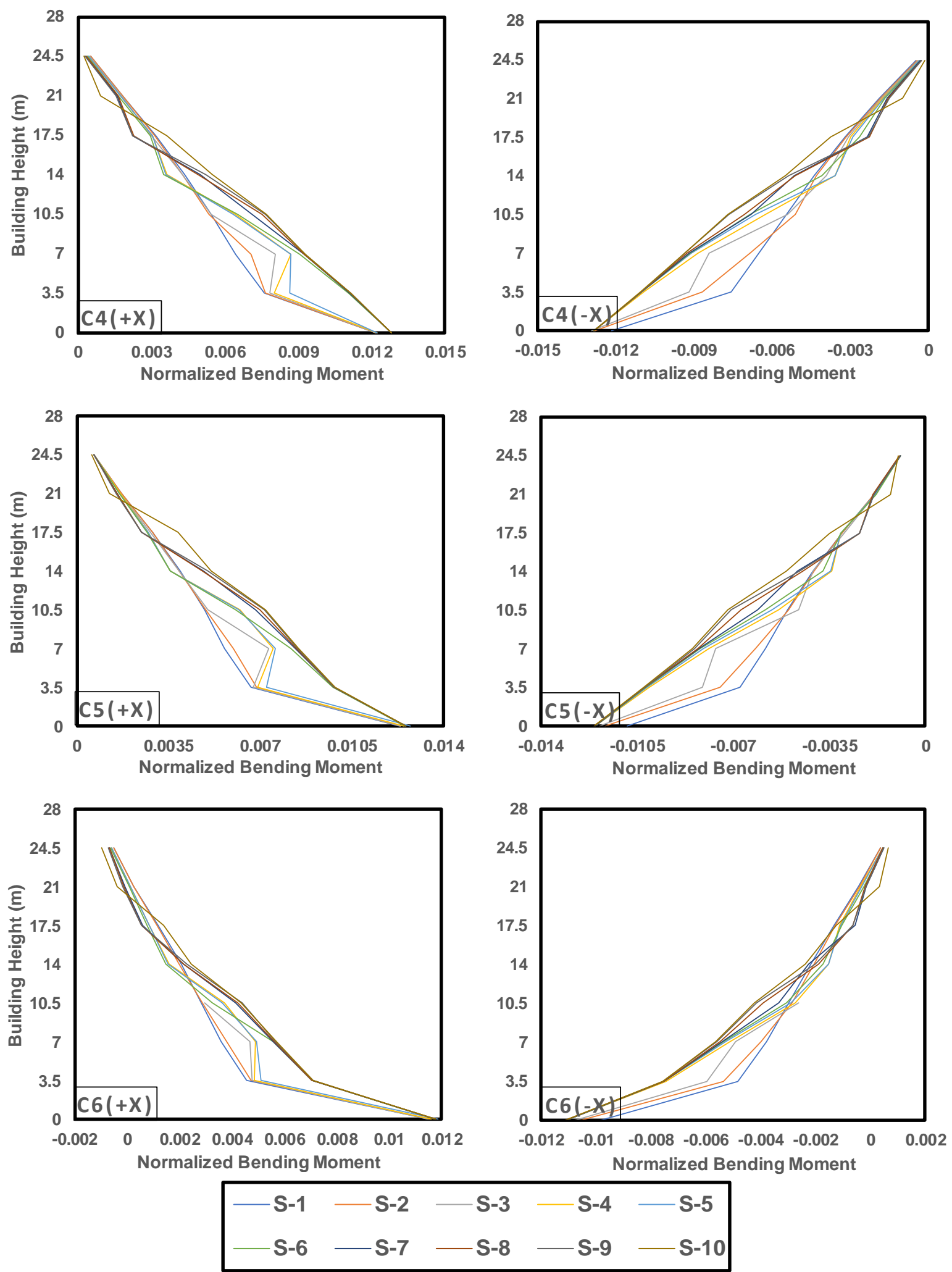

Figure 9. (cont'd). Normalized bending moments vs. Building height at the bottom of the columns for all steps in $+/-X$ loading directions. 

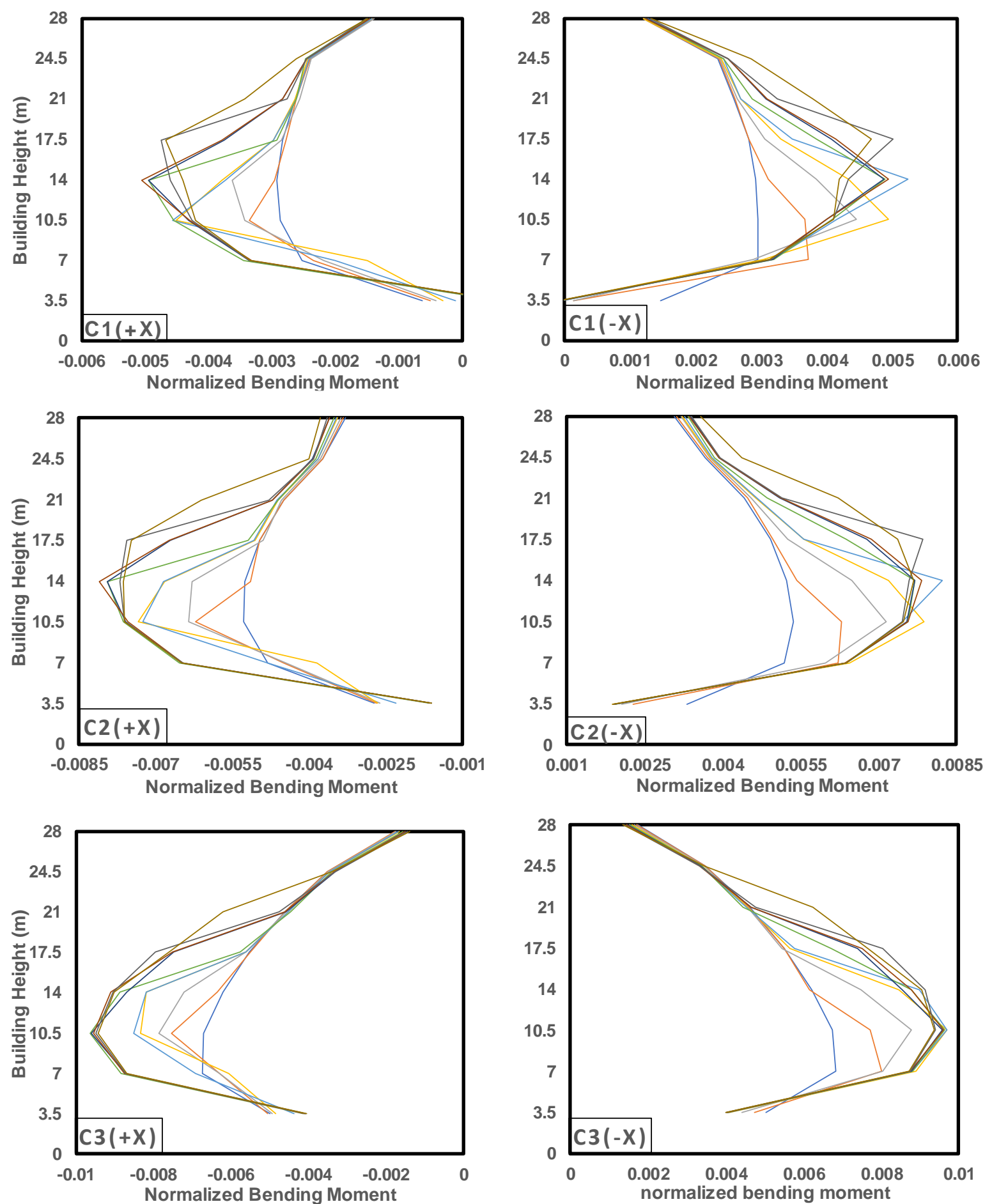

$$
\begin{array}{|rrrrr|}
\hline \mathrm{S}-1 & -\mathrm{S}-2 & -\mathrm{S}-3 & \mathrm{~S}-4 & -\mathrm{S}-5 \\
\mathrm{~S}-6 & -\mathrm{S}-7 & \mathrm{~S}-8 & \mathrm{~S}-9 & -\mathrm{S}-10 \\
\hline
\end{array}
$$

Figure 10. Normalized bending moments vs. Building height at the top of the columns for all steps in $+/-X$ loading directions. 

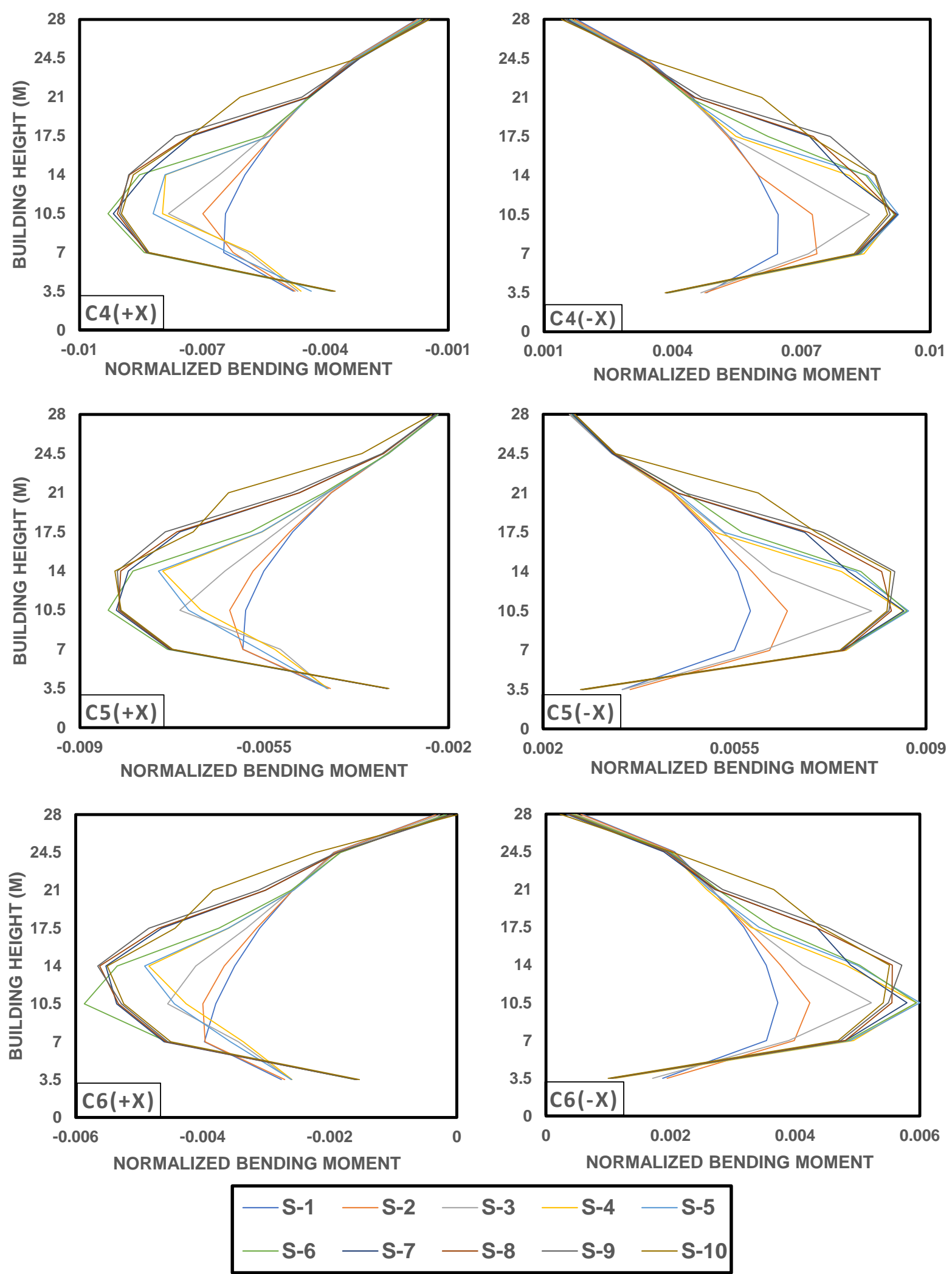

Figure 10. (cont'd). Normalized bending moments vs. Building height at the top of the columns for all steps in $+/-X$ loading directions.

\section{Conclusion}

A set of analyses were carried out to investigate the effects of unreinforced masonry infill walls on the structural response of 2D frame systems. The analysis was conducted with 10 steps for $+/$-X loading 
directions by controlling the base shear and extracting the struts that reached the axial load capacity. It was observed that the presence of unreinforced masonry infill walls has significant effects on the structural response in terms of decreasing story drifts and the natural period of the structural systems as well as affecting the interaction between the bending moments and the axial loads on the columns. Although several studies in the literature recommend using one strut [13-16] for representing the infill panels, and in code provisions [5] there is only one strut definition for simulation of the infill walls, the earthquake ground motion has an inverse loading effect which can be imposed in the model of the structural systems in both (+) and (-) directions. Within the scope of this study, the 2D frame system was intentionally selected as asymmetric along the elevation to emphasize the inadequacy of using one strut for simulation of infill panels.

Comparison between infilled frames subjected to earthquake loads in $+/-X$ loading directions revealed that using only one strut for simulation of infill walls is not sufficient for reliable response predictions of structural systems under earthquake ground motions. Even in these two analytical results, with the same parameters except altering the direction of the struts and earthquake loading directions, there are discrepancies between axial force and bending moment distributions as well as the natural periods and story drifts due to using diagonal struts in only one direction.

It was also observed that the first strut reaches capacity at the mid-height of the 2D frame system and some of the struts in the upper levels need significant base shear values to reach their axial load capacity. Thus, the analytical procedure proposed in the present study can be conveniently used to investigate the soft-story issue in the building systems.

As it is presented in many code provisions [6], not considering the effect of the infill walls in the design of the structural systems is not sufficient for simulating the actual response of them. Considering the infill walls in each span where the infill walls exist is also not a reliable approach, since they may fail under earthquake ground motion. Although the world tends to design and analysis the structural systems under nonlinear cases, there are simply designed structural systems that can be designed under linear cases due to consideration of time and effort for the relevant project. Hence, it is simply proposed in this study that in linear seismic analysis for any earthquake load level first define an axial load capacity for each strut that may be the one that was used herein. Second, conduct the analysis and delete the struts that reach the defined axial load capacity and rerun the analysis for obtaining the final model of the structural system.

Compared to infilled frame, bare frame shows significant values of drift, moment, shear forces, and period as well as small values of axial forces in columns. Consequently, ignoring the presence of infill walls in a structural system during the seismic design process can either overestimate or underestimate the behavioral response of that system. In other words, current code provisions should focus on the consideration of not only the weight of the infill panels but also their stiffness and interaction with frames.

\section{Author's Contribution}

Two authors contributed to the study.

\section{Statement of Conflicts of Interests}

No potential conflict of interest was reported by the authors.

\section{Statement of Research and Publications Ethics}

The authors declare that this study complies with Research and Publication Ethics.

\section{References}

[1] Mosalam K. M., Günay S. 2015. Progressive Collapse Analysis of Reinforced Concrete Frames with Unreinforced Masonry Infill Walls Considering In-plane/Out-of-plane Interaction. Earthquake Spectra, 31 (2): 921-943. 
[2] Mosalam K. M., White R. N., Gergely P. 1997 (a). Seismic Evaluation of Frames with Infill Walls Using Pseudo-Dynamic Experiments. In: National Center for Earthquake Engineering Research, Buffalo, NY, USA, NCEER-97-0020.

[3] Mosalam K. M., White R. N., Gergely P. 1997 (b). Seismic Evaluation of Frames with Infill Walls Using Quasi-Static Experiments. In: National Center for Earthquake Engineering Research, Buffalo, NY, USA, NCEER-97-0019.

[4] Korkmaz K. A., Demir F., Sivri M. 2007. Earthquake Assessment of R/C Structures with Masonry Infill Walls. International Journal of Science and Technology, 2 (2): 155-164.

[5] FEMA 356. 2000. Prestandard and Commentary for the Seismic Rehabilitation of Buildings. Federal Emergency Management Agency, USA, 1-518.

[6] Turkish Building Seismic Code. 2018. Prime Ministry, Disaster and Emergency Management Presidency (AFAD), Ankara, 1-395.

[7] Aksoylu C., Arslan M. H. 2019. Çerçeve+ Perde Türü Betonarme Binalarin Periyod Hesaplarinin TBDY-2019 Yönetmeliğine Göre Ampirik Olarak Değerlendirilmesi. Uludağ University Journal of the Faculty of Engineering, 24(3), 365-382.

[8] Aksoylu C., Mobark A., Hakan Arslan M., Hakk1 Erkan İ. 2020. A Comparative Study on ASCE 7-16, TBEC-2018 and TEC-2007 for Reinforced Concrete Buildings. Revista De La Construcción, 19(2), 282-305.

[9] Sezer R., Aksoylu C., Kara N. 2016. Investigation of Behavior of Structures According to Different Local Site Classes for L Type Reinforced Concrete Frame Building Having A1 and A3 Irregularities. TOJSAT, 6(1), 21-32.

[10] Aksoylu C., Arslan M. H. 2021. 2007 ve 2019 Deprem Yönetmeliklerinde Betonarme Binalar İçin Yer Alan Farklı Deprem Kuvveti Hesaplama Yöntemlerinin Karşılaştırılmalı Olarak İrdelenmesi. International Journal of Engineering Research and Development, 13(2), 359-374.

[11] Aksoylu C., Arslan, M. H. 2019. Çerçeve Türü Betonarme Binaların Periyod Hesaplarının Farklı Ampirik Bağıntılara Göre İrdelenmesi. Bitlis Eren Üniversitesi Fen Bilimleri Dergisi, 8(2), 569581.

[12] El-Dakhakhni W. W., Elgaaly M., Hamid A. A. 2003. Three-Strut Model for Concrete MasonryInfilled Steel Frames. Journal of Structural Engineering, 129 (2): 177-185.

[13] Madan A., Reinhorn A. M., Mander J. B., Valles R. E. 1997. Modeling of Masonry Infill Panels for Structural Analysis. Journal of Structural Engineering, 123 (10): 1295-1302.

[14] Mohyeddin-Kermani A., Goldsworthy H. M., Gad E. 2008. A Review of the Seismic Behaviour of RC Frames with Masonry Infill. Australian Earthquake Engineering Society Conference, 2023 Novamber, Ballarat, Victoraia, 38.

[15] Smith B. S. 1962. Lateral Stiffness of Infilled Frames. Journal of the Structural Division, 88 (6): 183-199.

[16] Das D., Murty C. V. R. 2004. Brick Masonry Infills in Seismic Design of RC Framed Buildings: Part 1-Cost implications. Indian Concrete Journal, 78 (7): 39-44.

[17] Rodrigues H., Varum H., Costa A. 2010. Simplified Macro-Model for Infill Masonry Panels. Journal of Earthquake Engineering, 14 (3): 390-416.

[18] CSI. 2020. Integrated Software for Structural Analysis and Design. SAP2000 v22.1.0. Computers and Structures Inc. Berkeley, CA, USA.

[19] Holmes M. 1961. Steel Frames with Brickwork and Concrete Infilling. Proceedings of the Institution of Civil Engineers, 19 (4): 473-478.

[20] Stafford S. B., Carter C., Mallick D. 1970. Discussion a Method of Analysis for Infilled Frames. Proceedings of the Institution of Civil Engineers, 46 (2): 229-231.

[21] Mainstone R. J., Weeks G. A. 1970. The Influence of a Bounding Frame on the Racking Stiffnesses and Strengths of Brick Walls. 2nd International Brick Masonry Conference, Building Research Establishment, 12-15 April,Watford, England, 165-171.

[22] Crisafulli F. J., Carr A. J. 2007. Proposed Macro-Model for the Analysis of Infilled Frame Structures. Bulletin of the New Zealand Society for Earthquake Engineering, 40 (2): 69-77.

[23] Kaushik H. B., Rai D. C., Jain S. K. 2007. Stress-Strain Characteristics of Clay Brick Masonry under Uniaxial Compression. Journal of Materials in Civil Engineering, 19 (9): 728-739.

[24] Panagiotakos T. B., Fardis M. N. 1996. Seismic Response of Infilled RC Frame Structures. 11th World Conference on Earthquake Engineering, 23-28 June, Acapulco, Mexico, 225. 
[25] Panagiotakos T. B., Fardis M. N. 1994. Proposed Nonlinear Strut Models for Infill Panels. University of Patras, Greece, 1st Year Progress Report of HCM-PREC8 Project.

[26] Tsai M. H., Huang T. C. 2011. Numerical Investigation on the Progressive Collapse Resistance of a RC Building with Brick Infills under Column Loss. International Journal of Engineering and Applied Sciences, 7 (1): 27-34.

[27] Dolšek M., Fajfar P. 2008. The Effect of Masonry Infills on the Seismic Response of a FourStorey Reinforced Concrete Frame - A Deterministic Assessment. Engineering Structures, 30 (7), 1991-2001.

[28] Žarnić R., Gostič S. 1997. Masonry Infilled Frames As an Effective Structural Sub-Assemblage. Seismic Design Methodologies for the next Generation of Codes, CRC Press, Florida, USA, 335346.

[29] Aksoylu C., Kara N. 2020. Strengthening of RC Frames by Using High Strength Diagonal Precast Panels. Journal of Building Engineering, 31, 101338.

[30] Aksoylu C., Kara N. 2019. Güçlendirme Tekniği Olarak Yeni Nesil Ön Üretimli Beton Panel Uygulamasının Araştırılması. Selçuk Üniversitesi Mühendislik, Bilim ve Teknoloji Dergisi, 7(2), 346-361.

[31] Saneinejad B. A., Hobbs B. 1995. Inelastic Design of Infilled Frames. Journal of Structural Engineering J., 121 (4): 634-650.

[32] Haldar P. 2012. Modeling of URM Infills and Their Effect on Seismic Behavior of RC Frame Buildings. The Open Construction and Building Technology Journal, 6 (1): 35-41. 